\title{
М.О. Андрущак
}

\section{ЗМІНИ КЛІТИННОГО ІМУНІТЕТУ У ВІЛ-ІНФІКОВАНИХ 3 ХРОНІЧНОЮ ХВОРОБОЮ НИРОК}

\author{
Буковинський державний медичний університет
}

\begin{abstract}
Мета роботи - встановити значення імунограми в оцінці ураження нирок ВІЛ-інфрікованих осіб.

Пацієнти і методи. Обстежено 292 хворих на ВІЛ-інфекцію, які перебували на амбулаторному спостереженні в Чернівецькому обласному центрі з профрілактики та боротьби зі СНІДом.

Результати. У ВІЛ-інфікованих осіб з хронічною хворобою нирок виявлено відхилення з боку абсолютного вмісту Т-хелперів, цитотоксичних Т-клітин, а також імунорегуляторного індексу.

На рівні субпопуляцій Т-лімфооцитів проявляються і статеві відмінності: у чоловіків порівняно з жінками підтверджено достовірно нижчий відсоток Т-хелперних

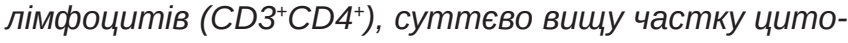
токсичних T-клітин $\left(C D 3^{+} C D 8^{+}\right) i$, відповідно, зниження імунорегуляторного індексу (в усіх випадках р<0,05).

У ВІЛ-інфрікованих з ураженням нирок достовірно знижені абсолютне й відносне числа $C D 3^{+} C D 4^{+}-к л і т и н$, імунорегуляторний індекс, а також абсолютне й відносне значення цитолітичних Т-лімфоцитів $\left(C D 3^{+} C D 56^{+}\right)$порівняно з ВІЛ-інфрікованими без патології нирок $(p<0,05)$.

При наростанні рівня протеїнурії у крові знижуєть-

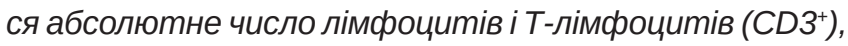
а також зростає відсоток та абсолютне число цитотоксичних Т-клітин $\left(C D 3^{+} C D 8^{+}\right)$. Однак кореляційний аналіз рівня протеїнурії та показників типової імунограми жодного значущого зв'язку не виявив.
\end{abstract}

Висновки. Можна стверджувати, що ураження нирок в осіб з ВІЛ-інфекцією розвивається на тлі суттєвішого падіння числа переважно Т-хелперної субпопуляції лімфоцитів.

Ключові слова: ВІЛ-інфекція, хронічна хвороба нирок, клітинний імунітет, імунограма.

Сучасна епідемічна ситуація в Україні не дає підстав стверджувати про суттєве зниження тягаря епідемії ВІЛінфекції - її масштаби продовжують зростати. Так, за оперативними даними ДУ «Центр громадського здоров'я м03 України»:
- за період 1987-2016 рр. в країні офріційно зареєстровано 297424 випадки ВІЛ-інфекції серед громадян України, у тому числі 92897 випадків СНІД і 41710 випадків смерті від захворювань, зумовлених СНІД;

- станом на 01.01.2017 р. під медичним наглядом перебуває майже 133 тис. ВІЛ-інфрікованих осіб, з них кожен третій має діагноз СНІД [1].

У 2016 р. в Україні спостерігалося збільшення кількості зареєстрованих ВІЛ-інфрікованих осіб - 17066 проти 15869 у 2015 р., темп приросту становив +7,5\%, показник захворюваності досяг 40,0 на 100 тис. населення проти 37,0 на 100 тис. у попередньому році [2].

Ураження нирок, яке нерідко характеризується тяжкими клінічними проявами, може істотно впливати на прогноз життя ВІЛ-інфрікованих [3, 4]. Враховуючи зростання числа ВІЛ-інфікованих у світі та збільшення тривалості життя таких хворих, слід чекати й збільшення кількості ВІЛ-інфрікованих осіб, які потребують дороговартісної замісної ниркової терапії, а також трансплантації нирки.

Незважаючи на велику кількість публікацій, присвячених цій темі, питання ураження нирок при ВІЛ-інфекції в Україні досі залишається недостатньо висвітленим.

Мета роботи - встановити значення імунограми в оцінці ураження нирок ВІЛ-інфрікованих осіб.

\section{Пацієнти і методи}

Обстежено 292 хворих на ВІЛ-інсекцію, які перебували на амбулаторному спостереженні в Чернівецькому обласному центрі з профрілактики та боротьби зі СНІДом (головний лікар В.М. Мочульський).

При встановленні діагнозу брали до уваги клініко-епідеміологічні дані та результати лабораторних методів дослідження: серологічного та імунологічного (у т.ч. визначення вмісту CD4+-лімфоцитів). Первинне обстеження ВІЛ-інфрікованих проводили при взятті їх на диспансерний облік згідно з КП № 580 від 12.12.2003 р.

Середній вік усіх хворих становив $(29,3 \pm 8,2)$ року (діапазон від 19 до 55 років). Серед пацієнтів було 188 $(64,4$ \%) чоловіків і 104 (35,6 \%) жінки. У дослідження 


\section{ОРИГІНАЛЬНІ ДОСЛІДЖЕННЯ}

переважно були включені хворі молодого віку (25-44 роки).

Серед пацієнтів, які були включені в дослідження, I клінічна стадія ВІЛ-інфекції виявлена у 26 (8,9\%) осіб, II - у 40 (13,7\%), III - у 108 (37,0 \%) і IV клінічна стадія - у $118(40,4 \%)$ хворих.

Функціональний стан нирок оцінювали за інтегральним показником, що характеризує ступінь збереження/втрати маси діючих нефронів. Критерієм порушення функції нирок було зниження швидкості клубочкової фрільтрації (ШКФ) $<60$ мл/хв на 1,73 м² $[5,6]$.

Хронічну хворобу нирок (XXH) діагностували при виявленні протеїнурії (ПУ) або протеїнурії у поєднанні зі зниженням ШКФ протягом 3 місяців і більше.

Скринінгове дослідження для виявлення маркерів пошкодження нирок (постійна протеїнурія, зниження ШКФ, що виявляються протягом 3 і більше місяців) у ВІЛ-інфрікованих проведене відповідно до рекомендацій Національного Ниркового Фонду (Kidney Disease Outcome Quality Initiative, K/DOQI, 2002) й Американської Асоціації $з$ Інфекційних хвороб (Infectious Diseases Society of America, IDSA, 2005) $[4,6]$.

Серед обстежених пацієнтів було 105 (36,0 \%) осіб 3 маркерами пошкодження нирок - альбумінурією/протеїнурією. На підставі основних маркерів пошкодження нирок - персистентної ПУ і ШКФ<60 мл/хв/1,73 м² - у 16,4 \% випадків діагностована XXH, яка з великою частотою супроводжувалася порушенням фрункції нирок.

ВІЛ-асоційована нефропатія встановлена у 48 з 292 (16,4 \%) хворих (31 чоловік, 17 жінок), в яких у процесі об- стеження були виявлені й підтверджені маркери пошкодження нирок - персистентна протеїнурія або протеїнурія у поєднанні зі зниженням ШКФ.

Матеріалом для дослідження показників типової імунограми була венозна кров, яку забирали у пацієнтів вранці натще у кількості 5 мл у пробірки Vacuum Tube EDTA.K3 (цільна кров). Методом проточної цитометрії протягом 2 год після забору здійснювали кількісне визначення субпопуляцій лімсроцитів з використанням моноклональних антитіл з подвійною міткою $[7,8]$.

Дослідження показників типової імунограми здійснювали у 40 пацієнтів з ВІЛ-інфекцією і маркерами пошкодження нирок. Група складалася з 23 чоловіків (57,5 \%) та 17 жінок (42,5\%), середній вікхворих становив $(34,3 \pm 7,9)$ року (діапазон від 21 до 52 років). Групу контролю склали 20 пацієнтів з ВІЛ-інфекцією без ознак ураження нирок, зіставних за віком, статтю й антропометричними показниками $з$ досліджуваним контингентом осіб із патологією нирок.

\section{Результати досліджень та їх обговорення}

На малюнку 1 й у таблиці 1 представлені результати типового імунологічного дослідження клітинного складу лімфроцитів та їх статистичної обробки. На малюнку представлені не власне значення показників у пацієнтів 3 ВІЛ-інфекцією і маркерами пошкодження нирок, а коесріцієнти їх відхилення (КВ) від контрольних значень (показники ВІЛ-інфрікованих пацієнтів без ознак ураження нирок), що обчислюються за фрормулою:

KB=100 \% $+\frac{\text { показник хворого - показник здорового }}{\text { показник здорового }} \times 100 \%$

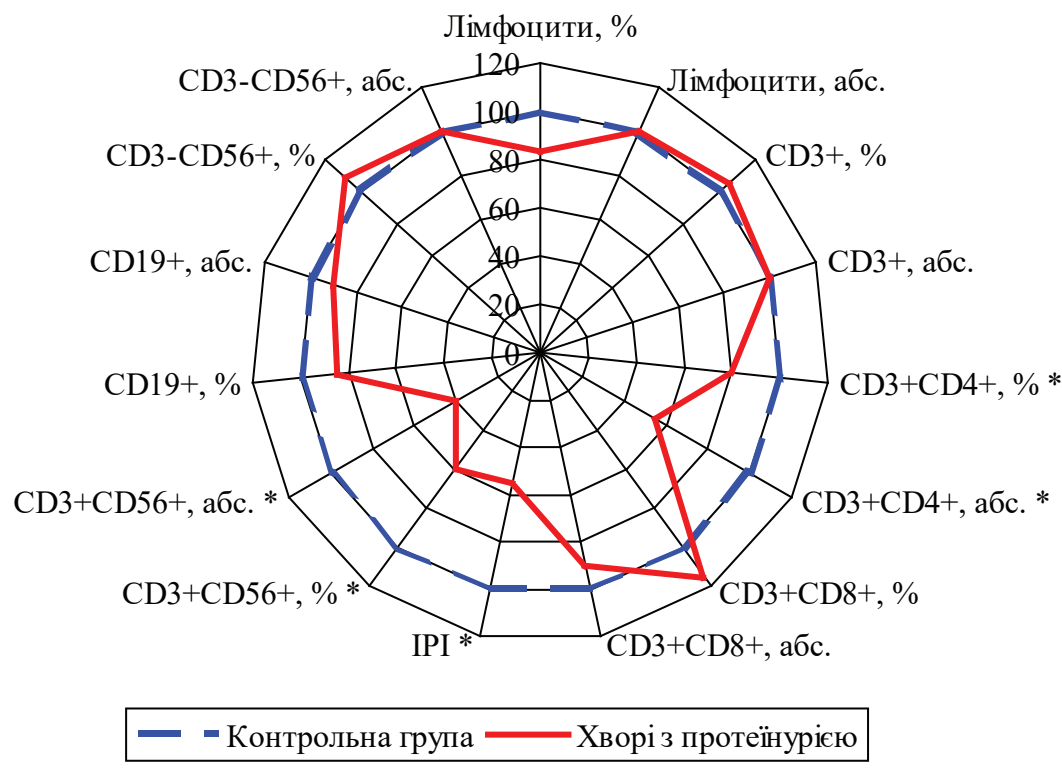

Примітка. * - значущі відмінності $(p<0,05)$.

Мал. 1. Коефріцієнти відхилення показників типової імунограми від контрольних значень у ВІЛ-інфрікованих хворих 3 протеїнурією (\%). 
Таблиця 1

Показники типових імунограм у ВІЛ-інфрікованих з наявністю і відсутністю протеїнурії, медіана [25 \%; 75 \%]

\begin{tabular}{|c|c|c|c|c|}
\hline \multirow{2}{*}{\multicolumn{2}{|c|}{ Показник }} & \multicolumn{2}{|c|}{ Протеїнурія } & \multirow{3}{*}{$\begin{array}{c}p \\
>0,05\end{array}$} \\
\hline & & \multirow{2}{*}{$\begin{array}{c}\epsilon(n=48) \\
28,5[20,2 ; 35,6]\end{array}$} & \multirow{2}{*}{$\begin{array}{c}\text { немає }(n=40) \\
32,3[25,3 ; 44,8]\end{array}$} & \\
\hline & $\%$ & & & \\
\hline ЛІМфроцИТИ & $\times 10^{9} 1 / \pi$ & $1,7[1,0 ; 2,4]$ & $1,6[1,2 ; 2,3]$ & $>0,05$ \\
\hline \multirow{2}{*}{$\mathrm{CD}^{+}$} & $\%$ & $79,6[74,0 ; 89,5]$ & $83,3[75,2 ; 88,1]$ & $>0,05$ \\
\hline & $\times 10^{9} 1 / л$ & $1,2[0,9 ; 2,0]$ & $1,2[1,1 ; 1,9]$ & $>0,05$ \\
\hline \multirow{2}{*}{$\mathrm{CD}^{+}{ }^{\mathrm{CD}} 4^{+}$} & $\%$ & $15,0[9,5 ; 22,2]$ & $23,6[19,7 ; 31,0]$ & $<0,05$ \\
\hline & $\times 10^{91 / \pi}$ & $0,2[0,1 ; 0,4]$ & $0,5[0,3 ; 0,7]$ & $<0,05$ \\
\hline \multirow{2}{*}{$\mathrm{CD}^{+}{ }^{\mathrm{CD}} 8^{+}$} & $\%$ & $57,6[48,5 ; 66,4]$ & $53,8[45,4 ; 64,1]$ & $>0,05$ \\
\hline & $\times 10^{9} 1 / \pi$ & $0,9[0,5 ; 1,5]$ & $0,8[0,5 ; 1,4]$ & $>0,05$ \\
\hline \multicolumn{2}{|l|}{ IPI } & $0,2[0,1 ; 0,4]$ & $0,4[0,3 ; 0,8]$ & $<0,05$ \\
\hline \multirow{2}{*}{$\mathrm{CD}^{+} \mathrm{CD}^{2} 6^{+}$} & $\%$ & $1,6[0,4 ; 4,6]$ & $3,2[1,5 ; 7,0]$ & $<0,05$ \\
\hline & $\times 10^{9} 1 / ת$ & $0,02[0,005 ; 0,05]$ & $0,05[0,03 ; 0,08]$ & $<0,05$ \\
\hline \multirow{2}{*}{$\mathrm{CD} 9^{+}$} & $\%$ & $7,1[4,9 ; 13,2]$ & $8,0[4,7 ; 15,6]$ & $>0,05$ \\
\hline & $\times 10^{9} 1 / \pi$ & $0,10[0,08 ; 0,16]$ & $0,18[0,11 ; 0,22]$ & $>0,05$ \\
\hline \multirow{2}{*}{ CD3-CD56 ${ }^{+}$} & $\%$ & $6,4[4,5 ; 11,4]$ & $6,5[4,2 ; 12,2]$ & $>0,05$ \\
\hline & $\times 10^{9} 1 / л$ & $0,11[0,08 ; 0,18]$ & $0,10[0,08 ; 0,21]$ & $>0,05$ \\
\hline
\end{tabular}

Як показують представлені ілюстрації, у хворих на ВІЛ-інфекцію з ураженням нирок достовірно знижені абсолютне й відносне числа CD3+CD4+-клітин, імунорегуляторний індекс (IPI), а також абсолютне й відносне значення цитолітичних Т-лімфоцитів $\left(\mathrm{CD}^{+} \mathrm{CD}^{+} 6^{+}\right)$порівняно з ВІЛ-інфрікованими без патології нирок $(p<0,05)$.
Таким чином, можна стверджувати, що ураження нирок в осіб з ВІЛ-інфекцією розвивається на тлі суттєвішого падіння числа переважно Т-хелперної субпопуляції лімфроцитів.

Дослідили зміни типових імунограм ВІЛ-інфрікованих з XXН залежно від статі (табл. 2).

Таблиця 2

Показники типових імунограм хворих з маркерами ушкодження нирок залежно від статі, медіана [25 \%; 75 \%]

\begin{tabular}{|c|c|c|c|c|}
\hline \multicolumn{2}{|c|}{ Показник } & Чоловіки, n=31 & Жінки, n=17 & $p$ \\
\hline \multirow{2}{*}{ Лімсроцити } & $\%$ & $28,2[19,5 ; 36,0]$ & $28,6[18,9 ; 34,1]$ & $>0,05$ \\
\hline & $\times 10^{9} 1 / ת$ & $1,6[0,9 ; 2,8]$ & $1,8[1,0 ; 2,3]$ & $>0,05$ \\
\hline \multirow{2}{*}{$\mathrm{CD}^{+}$} & $\%$ & $80,5[77,4 ; 85,7]$ & $78,8[69,6 ; 83,3]$ & $>0,05$ \\
\hline & $\times 10^{91} / л$ & $1,3[0,9 ; 2,1]$ & $1,1[0,9 ; 1,9]$ & $>0,05$ \\
\hline \multirow{2}{*}{$\mathrm{CD}^{+}{ }^{+} \mathrm{CD} 4^{+}$} & $\%$ & $12,4[6,6 ; 16,9]$ & $18,5[12,0 ; 32,5]$ & $<0,05$ \\
\hline & $\times 10^{9} 1 / л$ & $0,2[0,09 ; 0,3]$ & $0,3[0,2 ; 0,5]$ & $>0,05$ \\
\hline \multirow{2}{*}{$\mathrm{CD}^{+}{ }^{\mathrm{CD}} 8^{+}$} & $\%$ & $68,1[56,2 ; 72,5]$ & $52,3[38,0 ; 58,3]$ & $<0,05$ \\
\hline & $\times 10^{9} 1 / л$ & $0,9[0,5 ; 1,9]$ & $0,8[0,4 ; 1,2]$ & $>0,05$ \\
\hline \multicolumn{2}{|l|}{ IPI } & $0,18[0,10 ; 0,30]$ & $0,45[0,15 ; 0,70]$ & $<0,05$ \\
\hline \multirow{2}{*}{$\mathrm{CD}^{+} \mathrm{CD}^{2} 6^{+}$} & $\%$ & $1,9[0,5 ; 5,0]$ & $1,3[0,3 ; 3,8]$ & $>0,05$ \\
\hline & $\times 10^{9} 1 / \pi$ & $0,03[0,01 ; 0,04]$ & $0,02[0,002 ; 0,10]$ & $>0,05$ \\
\hline \multirow{2}{*}{$\mathrm{CD} 9^{+}$} & $\%$ & $6,5[3,0 ; 11,5]$ & $8,7[5,9 ; 15,3]$ & $>0,05$ \\
\hline & $\times 10^{9} 1 / л$ & $0,10[0,07 ; 0,13]$ & $0,10[0,09 ; 0,20]$ & $>0,05$ \\
\hline \multirow{2}{*}{$\mathrm{CD}^{-} \mathrm{CD}^{-} 6^{+}$} & $\%$ & $6,2[4,2 ; 10,5]$ & $6,6[4,8 ; 12,1]$ & $>0,05$ \\
\hline & $\times 10^{9} 1 / л$ & $0,10[0,07 ; 0,16]$ & $0,12[0,09 ; 0,20]$ & $>0,05$ \\
\hline
\end{tabular}




\section{ОРИГІНАЛЬНІ ДОСЛІДЖЕННЯ}

Аналіз наведених у таблиці показників засвідчив достовірно нижчий відсоток Т-хелперних лімфоцитів $\left(\mathrm{CD} 3^{+} \mathrm{CD} 4^{+}\right)$у чоловіків порівняно з жінками - $(12,4$ [6,6; $16,9])$ проти $(18,5$ [12,0; 32,5]) \%, суттєво вищу частку цитотоксичних Т-клітин (CD3+CD8+ $-(68,1[56,2 ; 72,5])$ проти $(52,3$ [38,0; 58,3]) \% і, відповідно, зниження імунорегуляторного індексу - 0,18 [0,10; 0,30] проти 0,45 [0,15; $0,70]$ (в усіх випадках $\mathrm{p}<0,05$ ).
При зіставленні імунологічних показників хворих на ВІЛ-інфекцію з різним рівнем протеїнурії виявляються різноспрямовані зрушення ряду значень (табл. 3). 3окрема встановили, що при наростанні рівня протеїнурії знижується абсолютне число лімфроцитів і Т-лімфоцитів $\left(\mathrm{CD}^{+}\right)$, а також зростає відсоток та абсолютне число цитотоксичних Т-клітин (CD3+CD8 $\left.{ }^{+}\right)$(мал. 2).

Таблиця 3

Показники типових імунограм ВІЛ-інорікованих з різним рівнем протеїнурії, медіана [25 \%; 75 \%]

\begin{tabular}{|c|c|c|c|c|c|c|c|}
\hline \multirow{2}{*}{\multicolumn{2}{|c|}{ Показник }} & \multicolumn{3}{|c|}{ Рівень протеїнурії } & \multirow{3}{*}{$\frac{\mathrm{p}_{1-2}}{>0,05}$} & \multirow{3}{*}{$\frac{p_{1-3}}{<0,05}$} & \multirow{3}{*}{$\begin{array}{c}\mathrm{p}_{2-3} \\
<0,05\end{array}$} \\
\hline & & \multirow{2}{*}{$\begin{array}{c}<1,0 \text { г/добу, n=27 } \\
30,2 \text { [21,5; 38,0] }\end{array}$} & \multirow{2}{*}{$\begin{array}{c}\text { 1,0-3,0 г/добу, n=14 } \\
31,8 \text { [22,0; 39,5] }\end{array}$} & \multirow{2}{*}{$\begin{array}{l}\text { >3,0 г/добу, n=7 } \\
23,0[17,3 ; 29,9]\end{array}$} & & & \\
\hline Ming houт & $\%$ & & & & & & \\
\hline ЛІМфроциІи & $\times 10^{9} 1 / \pi$ & $2,2[1,1 ; 2,6]$ & $1,7[1,0 ; 2,5]$ & $1,2[0,7 ; 1,7]$ & $<0,05$ & $<0,05$ & $<0,05$ \\
\hline \multirow{2}{*}{$\mathrm{CD}^{+}$} & $\%$ & $80,2[75,6 ; 89,6]$ & $81,5[76,0 ; 90,8]$ & $79,8[68,9 ; 88,6]$ & $>0,05$ & $>0,05$ & $>0,05$ \\
\hline & $\times 10^{9} 1 / л$ & $2,0[1,2 ; 2,3]$ & $1,7[1,0 ; 2,2]$ & $0,8[0,6 ; 1,2]$ & $>0,05$ & $<0,05$ & $<0,05$ \\
\hline \multirow{2}{*}{$\mathrm{CD}^{+}{ }^{+} \mathrm{CD} 4^{+}$} & $\%$ & $14,0[6,2 ; 20,4]$ & $17,1[10,5 ; 23,1]$ & $15,3[9,7 ; 22,9]$ & $<0,05$ & $>0,05$ & $>0,05$ \\
\hline & $\times 10^{9} 1 / л$ & $0,2[0,1 ; 0,5]$ & $0,15[0,08 ; 0,4]$ & $0,2[0,1 ; 0,4]$ & $>0,05$ & $>0,05$ & $>0,05$ \\
\hline \multirow{2}{*}{$\mathrm{CD}^{+} \mathrm{CD}^{+}$} & $\%$ & $50,8[36,5 ; 60,6]$ & $58,1[49,2 ; 68,5]$ & $65,3[58,0 ; 72,6]$ & $<0,05$ & $<0,05$ & $<0,05$ \\
\hline & $\times 10^{9} 1 / \pi$ & $0,6[0,4 ; 1,1]$ & $0,9[0,5 ; 1,5]$ & $1,2[0,7 ; 2,0]$ & $<0,05$ & $<0,05$ & $<0,05$ \\
\hline \multicolumn{2}{|l|}{ IPI } & $0,15[0,10 ; 0,53]$ & $0,22[0,17 ; 0,60]$ & $0,23[0,18 ; 0,72]$ & $>0,05$ & $>0,05$ & $>0,05$ \\
\hline \multirow{2}{*}{$\mathrm{CD}^{+} \mathrm{CD}^{2} 6^{+}$} & $\%$ & $1,8[0,5 ; 5,0]$ & $2,0[0,5 ; 5,5]$ & $1,6[0,4 ; 4,9]$ & $>0,05$ & $>0,05$ & $>0,05$ \\
\hline & $\times 10^{9} 1 / \pi$ & $0,03[0,01 ; 0,08]$ & $0,02[0,005 ; 0,06]$ & $0,015[0,005 ; 0,04]$ & $>0,05$ & $>0,05$ & $>0,05$ \\
\hline \multirow{2}{*}{ CD19+ } & $\%$ & $9,3[5,5 ; 16,7]$ & $7,5[4,8 ; 14,1]$ & $6,8[3,3 ; 9,9]$ & $>0,05$ & $<0,05$ & $>0,05$ \\
\hline & $\times 10^{9} 1 / ת$ & $0,12[0,10 ; 0,21]$ & $0,10[0,09 ; 0,18]$ & $0,10[0,07 ; 0,14]$ & $>0,05$ & $>0,05$ & $>0,05$ \\
\hline \multirow{2}{*}{ CD3-CD56 ${ }^{+}$} & $\%$ & $6,5[4,6 ; 12,2]$ & $6,8[4,8 ; 11,5]$ & $6,1[4,0 ; 10,6]$ & $>0,05$ & $>0,05$ & $>0,05$ \\
\hline & $\times 10^{9} 1 / л$ & $0,13[0,09 ; 0,20]$ & $0,11[0,07 ; 0,16]$ & $0,10[0,06 ; 0,15]$ & $>0,05$ & $>0,05$ & $>0,05$ \\
\hline
\end{tabular}

Примітки: $p_{1-2}$ - достовірна різниця між показниками у хворих 1-ї і 2-ї груп; $p_{1-3}$ - у пацієнтів 1-ї і 3-ї груп; $p_{2-3}$ - в осіб 2-ї і 3-ї груп.

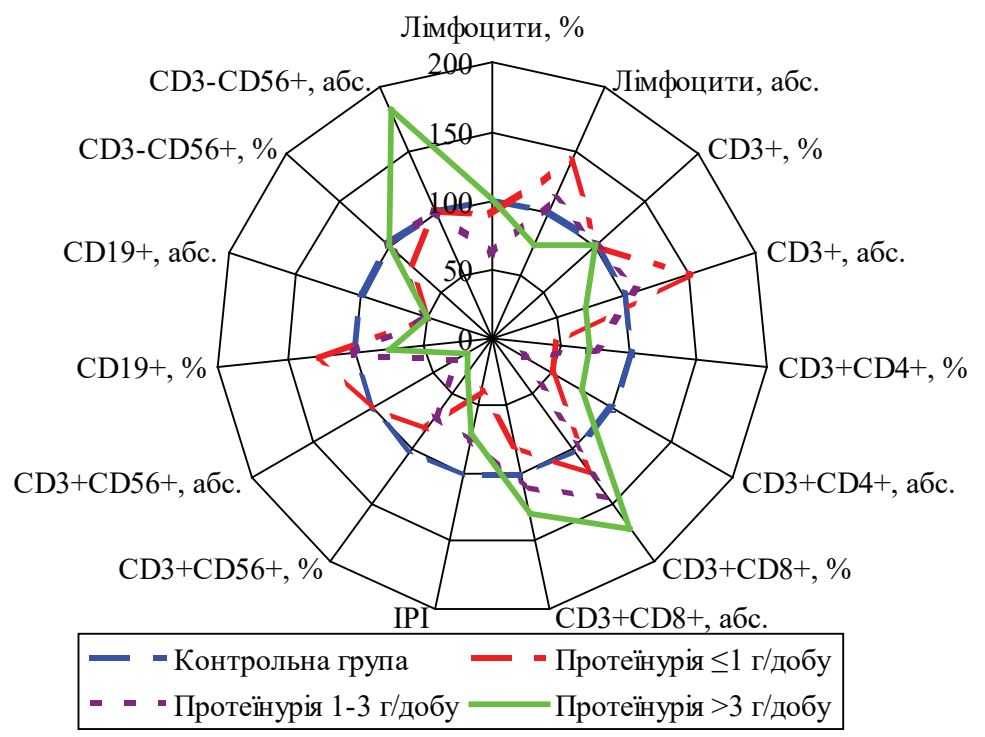

Мал. 2. Коефіцієнти відхилення показників типової імунограми від контрольних значень ВІЛ-інфрікованих залежно від рівня протеїнурії (\%). 
Таким чином, у ВІЛ-інфрікованих осіб з хронічною хворобою нирок виявлено відхилення з боку абсолютного вмісту Т-хелперів, цитотоксичних Т-клітин, а також імунорегуляторного індексу. На рівні субпопуляцій Т-лімфроцитів проявляються і статеві відмінності. При групуванні даних за рівнем протеїнурії для визначення популяційного і субпопуляційного складу лімфроцитів у крові були встановлені відмінності між загальною кількістю лімфроцитів, абсолютним числом Т-лімфроцитів і цитотоксичними Т-клітинами.

Кожен з показників, що зазнавав достовірних змін, аналізували на рівні діапазону індивідуальних значень у пацієнтів з XXH і у контрольній групі. У хворих з маркерами пошкодження нирок по діапазону значень відхилялися усі три показники - відносний і абсолютний

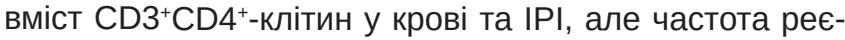
страції специфрічних для ураження нирок критерійних значень показника становила тільки 38, 32 і 36 \% відповідно. Оскільки показник можна віднести до критерійних ознак, якщо він реєструється більш ніж у 70 \% хворих, зміни типової імунограми в осіб з ХХН не є критерійними, незважаючи на реєстрацію відхилень у показниках.

Описані нами зміни клітинного складу лімсоцитів типової імунограми у ВІЛ-інфікованих 3 маркерами ушкодження нирок збігаються 3 даними досліджень, проведених в інших країнах. Слід додати, що в одному з когортних досліджень, здійснених у США, був встановлений взаємозв'язок між наявністю протеїнурії і збільшенням кількості активних $\mathrm{CD}^{+}$-лімфроцитів у крові ВІЛ-інфрікованих [9]. Однозначної інтерпретації отрима- них результатів нині немає. 3 одного боку, як припускають автори, недропатія (протеїнурія) викликає активацію системного імунітету при ВІЛ-інфекції, і тим самим призводить до несприятливого висліду недуги. Це відбувається за рахунок наявності постійного вогнища запалення, зумовленого реплікацією ВІЛ у нирках, що своєю чергою призводить до активації місцевої і системної імунної відповіді. 3 другого боку, при активації імунної системи посилюється інфрільтрація активних Т-лімфроцитів в інтерстицій нирок, що призводить до їх ушкодження [9].

\section{Висновки}

1. У ВІЛ-інфікованих з ураженням нирок достовірно знижені абсолютне й відносне числа $\mathrm{CD} 3^{+} \mathrm{CD} 4^{+}$-клітин, імунорегуляторний індекс, а також абсолютне й відносне значення цитолітичних Т-лімфоцитів (CD3 $\left.{ }^{+} \mathrm{CD} 56^{+}\right)$ порівняно з ВІЛ-інфікованими без патології нирок $(p<0,05)$. Таким чином, в осіб з ВІЛ-інфекцією ураження нирок розвивається на тлі суттєвішого падіння числа переважно Т-хелперної субпопуляції лімфоцитів.

2. На рівні субпопуляцій Т-лімфроцитів проявляються і статеві відмінності: у чоловіків порівняно з жінками підтверджено достовірно нижчий відсоток Т-хелперних лімфоцитів $\left(\mathrm{CD}^{+} \mathrm{CD} 4^{+}\right)$, суттєво вищу частку цитотоксичних Т-клітин $\left(\mathrm{CD}^{+} \mathrm{CD}^{+}\right) \mathrm{i}$, відповідно, зниження імунорегуляторного індексу (в усіх випадках p<0,05).

3. При наростанні рівня протеїнурії у крові знижується абсолютне число лімфоцитів і Т-лімфоцитів (CD3 ${ }^{+}$), а також зростає відсоток та абсолютне число цитотоксичних Т-клітин (CD3 $\left.{ }^{+} \mathrm{CD}^{+}\right)$.

\section{Література}

1. Інформація про епідемічну ситуацію з ВІЛ-інфекції в Україні станом на 01.01.2017 р. [Електронний ресурс]. Режим доступу: https://www.google.com.ua/ http://phc.org.ua/uploads/ documents/83da57/

2. Андрейчин М.А. Небезпечна динаміка інфекційної захворюваності в Україні / М.А. Андрейчин // Інфекційні хвороби. - 2017. - № 2(88). - С. 4-8.

3. ВИЧ-инфрекция. Клиника, диагностика и лечение / В.В. Покровский, Т.Н. Ермак, В.В. Беляева, О.Г. Юрин. - М.: ГЭОТАР-МЕД, 2003. - 488 c.

4. Guidelines for the management of chronic kidney disease in HIV-infected patients: recommendations of the HIV Medicine Association of the Infectious Diseases Society of America / S.K. Gupta, J.A. Eustace, J.A. Winston [et al.] // Clin. Infect. Dis. - 2005. - Vol. 80, N 11. - P. 1559-1585.
5. Шилов Е.М. Нефрология / Е.М. Шилов. - М.: гЭОТАР - Медиа, 2008. - 696 с.

6. National Kidney Foundation (NKF). K/DOQI clinical practice guidelines for chronic kidney disease: evaluation, classification, and stratification. NKF [online] // Am. J. Kidney Dis. - 2002. - N 39. P. 251-266.

7. Jackson A. Basic phenotyping of lymphocytes: Selection and testing of reagents and interpretation of data / A. Jackson // Clin. Immunol. Newslett. - 2000. - Vol. 10. - P. 43-55.

8. Foucar K. Clinical application of immunologic techniques to the diagnosis of lymphoproliferative and immunodeficiency disorders / K. Foucar, J.A. Glueken // Lab. Medicine. - 2002. - Vol. 13. - P. 403-413.

9. HIV-1 infection initiates an inflammatory cascade in human renal tubular epithelial cells / M.J. Ross, C. Fan, M.D. Ross [et al.] // AIDS. - 2006. - Vol. 42, N 1. - P. 1-11. 


\section{References}

1. Informatsiya pro epidemichnu sytuatsiyu z VIL-infektsiyi v Ukrayini stanom na 01.01.2017 r. [Information on the epidemic situation with HIV in Ukraine as of 01.01.2017] [E-resource]. - 2017. Retrieved from: https://www.google.com.ua/ http://phc.org.ua/uploads/ documents/83da57 [in Ukrainian].

2. Andreychyn, M.A. (2017). Nebezpechna dynamika infektsiynoyi zakhvoryuvanosti $v$ Ukrayini [The dangerous dynamics of infectious diseases in Ukraine]. Infektsiyni khvoroby, 2(88), 4-8 [in Ukrainian].

3. Pokrovskiy, V.V., Ermak, T.N., Belyayeva, V.V., Yurin, O.H. (2003). VICh-infektsiya. Klinika, diagnostika i lecheniye [HIV-infection. Clinic, diagnostics and treatment]. M.: GEOTAR-MED, 488. [in Russian].

4. Gupta, S.K., Eustace, J.A., Winston, J.A. (2005). Guidelines for the management of chronic kidney disease in HIV-infected patients: recommendations of the HIV Medicine Association of the Infectious Diseases Society of America. Clin. Infect. Dis., 80(11), 1559-1585.

5. Shylov, E.M., (2008). Nefrologiya [Nefroulogy]. M.: GEOTARMedia, 696. [in Russian].

\section{CHANGES OF CELL IMMUNITY IN HIV- INFECTED WITH CHRONIC KIDNEY DISEASE}

\section{M.O. Andrushchak}

Bukovynian State Medical University

SUMMARY. The aim of the work - to determine the value of immunograms in assessing HIV-infected persons.

Patients and methods. Objective 292 HIV-infected patients, who were on an outpatient screening at the Chernivtsi Regional AIDS Center, were screened.

Results. In HIV-infected persons with chronic kidney disease, deviations from the side have been detected absolute content of T-helper cells, cytotoxic T-cells, as well as immunoregulatory index. At the level of subpopulations of T-lymphocytes sexual differences are manifested. At grouping data on the level of proteinuria to determine population and subpopulations the composition of lymphocytes in the blood were determined by the differences between the total amount lymphocytes, absolute number of T-lymphocytes and cytotoxic T-cells. Conclusions. The absolute and relative numbers of $C D 3^{+} C D 4^{+}$-cells, immunoregulatory index, and absolute and relative values of cytolytic T-lymphocytes $\left(C D 3^{+} C D 56^{+}\right)$in HIV-infected patients with renal impairment were significantly lower in comparison with HIV-infected patients without kidney disease $(p<0.05)$. Thus, it can be argued that kidney damage in people with HIV develops in the context of a more significant drop in the number of predominantly T-helper subpopulations of lymphocytes.

At the level of subpopulations of T-lymphocytes, sexual differences are also manifested: in men, compared to
6. National Kidney Foundation (NKF). (2002). K/DOQI clinical practice guidelines for chronic kidney disease: evaluation, classification, and stratification. NKF [online]. Am. J. Kidney Dis., 39, 251-266.

7. Jackson, A. (2000). Basic phenotyping of lymphocytes: Selection and testing of reagents and interpretation of data. Clin. Immunol. Newsletter, 10(4), 43. http://dx.doi.org/10.1016/0197-1859(90)90023-2

8. Foucar, K., \& Goeken, J. (1982). Clinical Application of Immunologic Techniques to the Diagnosis of Lymphoproliferative and Immunodeficiency Disorders. Laboratory Medicine, 3(7), 403-413. http://dx.doi.org/10.1093/labmed/13.7.403

9. Ross, M., Fan, C., Ross, M., Chu, T., Shi, Y., \& Kaufman, L. (2006). HIV-1 Infection Initiates an Inflammatory Cascade in Human Renal Tubular Epithelial Cells. JAIDS Journal of Acquired Immune Deficiency Syndromes, 42(1), 1-11. http://dx.doi.org/10.1097/01. qai.0000218353.60099.4f

women, a significantly lower percentage of T-helper lymphocytes $\left(C D 3^{+} C D 4^{+}\right)$, a significantly higher proportion of cytotoxic $T$ cells $\left(C D 3^{+} C D 8^{+}\right)$and, correspondingly, a lowering of the immunoregulatory index (in all cases $p<0.05$ ).

With an increase in the level of proteinuria in the blood, the absolute number of lymphocytes and T-lymphocytes $\left(C D 3^{+}\right)$decreases, as well as the percentage and absolute number of cytotoxic T-cells $\left(C D 3^{+} C D 8^{+}\right)$ increases. However, no correlation analysis of proteinuria and immunohistochemistry rates showed any significant association.

Key words: HIV infection, chronic kidney disease, cellular immunity, immunogram.

\section{Відомості про автора}

Андрущак Маргарита Олександрівна - асистент кафедри внутрішньої медицини та інфекційних хвороб Вищого державного навчального закладу України «Буковинський державний медичний університет»; margaritaassistent@ gmail.com

\section{Information about author}

Andrushchak M.O. - assistant of the Department of Internal Medicine and Infectious Diseases, Higher State Educational Establishment of Ukraine «Bukovynian State Medical University»; margaritaassistent@gmail.com

Конфрлікту інтересів немає.

Author has no conflict of interest to declare.

Отримано 23.08.2017 p. 